\title{
De mislukte unificatie van Unilever
}

\author{
Drs.R.Abma*
}

\begin{abstract}
Dit artikel beschrijft de belangrijkste redenen van de mislukte eenwordingsoperatie van Unilever in 2018. Een gebrekkige communicatie over de voor-en nadelen van de verschillende alternatieven voor de herziening van de vennootschappelijke structuur, een gebrek aan voorafgaande consultatie van de belangrijkste aandeelhouders en een onderschatting van de Brexit-sentimenten hebben het Unilever-bestuur waarschijnlijk de das omgedaan.
\end{abstract}

\section{Inleiding}

Op 17 februari 2017 maakten Unilever PLC en Unilever NV (hierna ook: Unilever-groep) bekend dat zij van hun concurrent The Kraft Heinz Company (hierna: Kraft Heinz) een potentieel openbaar bod hadden ontvangen op al hun aandelen ter waarde van om en nabij USD 143 miljard (ongeveer EUR 130 miljard). Het bod werd door het gezamenlijke bestuur van de Unilever-groep in krachtige bewoordingen afgewezen. Dat was niet zonder resultaat: twee dagen later trok Kraft Heinz het overnamevoorstel in. Het feit dat een partij een bod op de Unilever-groep had overwogen, toonde wel aan dat de producent van voedsel, huishoudelijke producten en persoonlijke verzorgingsproducten kwetsbaarheden kende. Het bestuur van de Unilever-groep kondigde op 6 april 2017 daarom aan de financiële doelstellingen aan te scherpen, de 'smeerselsdivisie' (zoals margarine, pindakaas enzovoort) te verkopen, het dividend te verhogen, aandelen in te kopen en beide Unilever-entiteiten te unificeren (met één aandelenklasse, één hoofdkantoor en één statutaire zetel). Op 15 maart 2018 kondigde het bestuur aan dat het had besloten om zowel het hoofdkantoor, de belastingresidentie, als de statutaire zetel van het geünificeerde Unilever in Nederland te plaatsen; het 'nieuwe' Unilever zou een Nederlandse naamloze vennootschap worden (hierna ook 'het bestuursbesluit' genoemd). Het bestuursbesluit moest nog wel door de algemene vergaderingen van Unilever NV en Unilever PLC worden goedgekeurd. Deze algemene vergaderingen werden voor 25 respectievelijk 26 oktober 2018 belegd. Op 5 oktober 2018 werden de beide vergaderingen geschrapt omdat gaandeweg bleek dat het bestuursbesluit niet op de steun van een 'significante groep van aandeelhouders' kon rekenen. ${ }^{1}$ Dit artikel gaat in op de achtergronden van de unificatie, de beweegredenen om te kiezen voor de plaatsing van zowel de statutaire zetel als het

\footnotetext{
* Drs. R. Abma is directeur bij Eumedion te Den Haag.

1. Persbericht van de Unilever-groep d.d. 5 oktober 2018.
}

hoofdkantoor in Nederland en de bezwaren hiertegen van die 'significante groep van aandeelhouders'.

\section{Achtergrond van het voornemen tot unificatie van Unilever}

Unilever ontstond op 1 januari 1930 uit de grensoverschrijdende fusie tussen het Britse Lever Brothers Limited en de Nederlandse Naamlooze Vennootschap Margarine Unie. In tegenstelling tot wat heden ten dage gebruikelijk is, kozen de fuserende vennootschappen er om belastingtechnische rede$n^{n} n^{3}$ voor om niet een van de fuserende vennootschappen te laten verdwijnen of om één topholding op te richten die de aandelen zou houden in beide vennootschappen, maar om twee beursgenoteerde topholdings te houden met twee afzonderlijke soorten aandelen. ${ }^{4}$ De ene topholding is Unilever NV, een vennootschap naar het recht van Nederland, waarvan de (verschillende soorten van (certificaten van)) aandelen worden verhandeld aan de effectenbeurzen van Amsterdam en New York. ${ }^{5}$ De andere topholding is Unilever PLC, een vennootschap naar het recht van Engeland en Wales, waarvan de aandelen worden verhandeld aan de effectenbeurzen van Londen en New York. ${ }^{6}$ Tegelijkertijd werd afgesproken dat Unilever NV en Unilever PLC zo veel mogelijk als één vennootschap zouden opereren, zowel bestuurlijk als economisch. Dit werd door de jaren heen mogelijk gemaakt door een aantal overeenkomsten die tussen de NV en de PLC waren gesloten (de zogenoemde constitutionele overeenkomsten of Foundation Agreements) en door bijzondere bepalingen in de statuten van de NV en de PLC. De NV en de PLC hebben dezelfde bestuurders en passen dezelfde waarderingsgrondslagen toe. Aandeelhouders ${ }^{7}$ van beide vennootschappen ontvangen dividenden op geëgaliseerde basis. Voor consolidatiedoeleinden vormen Unilever NV, Unilever PLC en hun dochtermaat-

2. Dit artikel is gebaseerd op persberichten van Unilever en andere relevante documenten die zijn geplaatst op haar website, www.unilever. com. Daarnaast is gebruik gemaakt van een groot aantal artikelen die naar aanleiding van de unificatie zijn verschenen in verschillende media.

3. W. Wennekes, De aartsvaders, Amsterdam: Olympus 2005, p. 264.

4. Hierna ook te noemen: beursvennootschap met een duale structuur.

5. De aandelen van Unilever NV die aan de beurs van New York worden verhandeld, heten New York Registry Shares (NYRSs). Het register wordt bijgehouden door Deutsche Bank Trust Company Americas. Zie hierover ook M.A. Desai, The decentering of the global firm, The World Economy 2009, afl. 9, p. 1271-1290.

6. De handel in de aandelen van Unilever PLC aan de beurs van New York vindt formeel plaats via zogenoemde American Depositary Shares (ADSs; soort certificaat), uitgegeven door Deutsche Bank Trust Company Americas.

7. Onder 'aandeelhouders' wordt in dit artikel ook verstaan de certificaathouders van Unilever NV. 


\section{Maandblad}

Ondernemingsrecht

\section{Figuur 1 De Unilever-structuur}

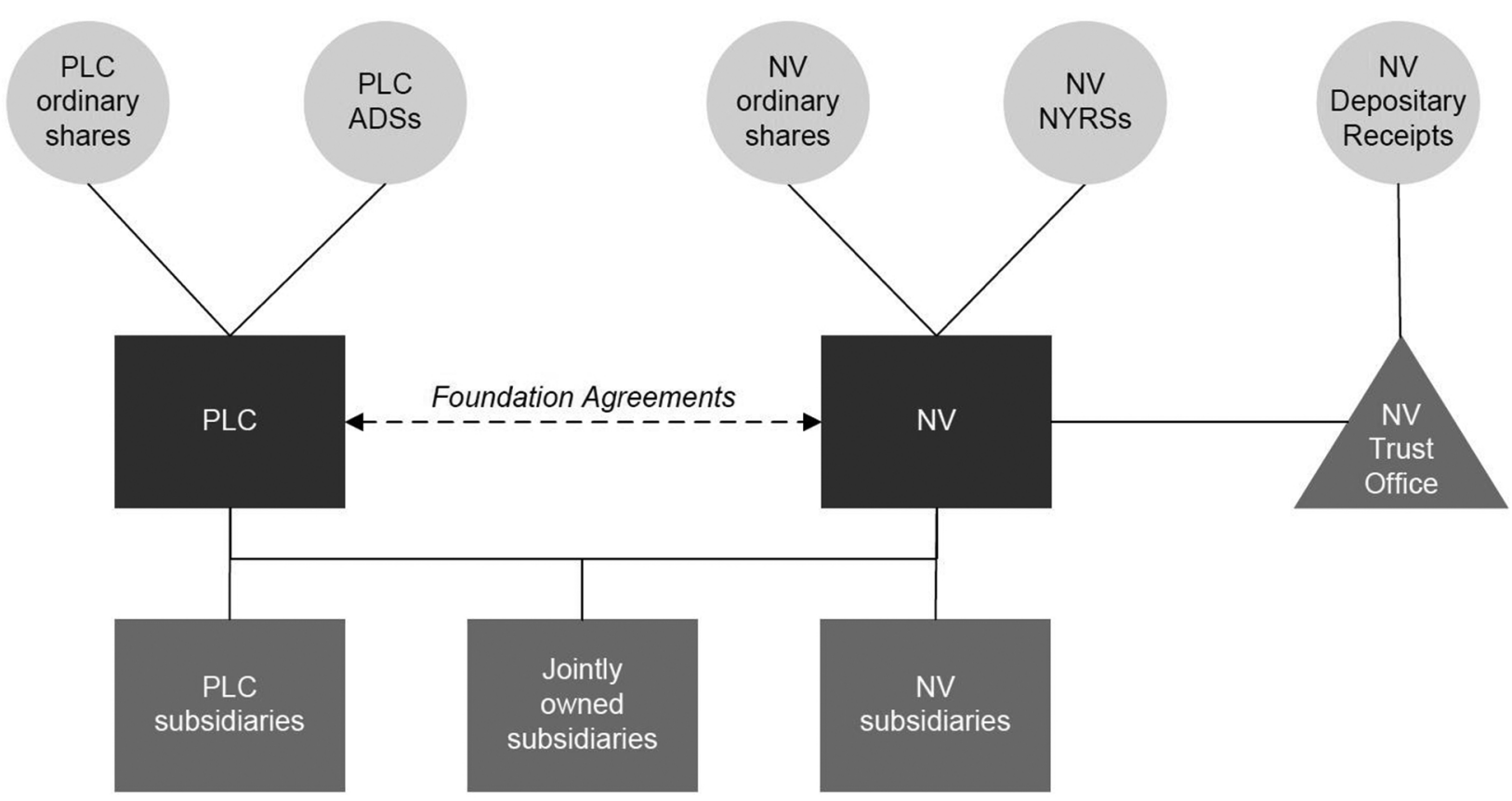

Bron: aandeelhouderscirculaire bij de juridische fusie, gepubliceerd op 11 september 2018, p. 7.

schappijen één groep. Aandelen in groepsmaatschappijen worden gehouden door de NV of de PLC of, in verschillende verhoudingen, door beide vennootschappen gezamenlijk. Schematisch ziet dit eruit als in figuur 1 .

Ondanks de bestuurlijke en economische samensmelting van de beide entiteiten kleeft er een aantal nadelen aan een beursvennootschap met een duale structuur. Zo moeten de twee beursgenoteerde topholdings separate algemene vergaderingen houden om bepaalde besluiten door de aandeelhouders te laten vaststellen of te laten goedkeuren, moeten zij zich onder meer houden aan twee stelsels van vennootschapsrecht en effectenrecht, en hebben zij te maken met ten minste twee effectenmarkttoezichthouders, twee accountantsorganisaties en twee belastingresidenties. Aangezien de beide vennootschappen verschillende soorten aandelen hebben uitgegeven, kennen zij ook verschillende aandeelhouders. Aandeelhouders van de ene topholding kunnen de aandelen niet converteren of omwisselen in aandelen van de andere topholding. Al deze factoren kunnen afbreuk doen aan de transparantie en eenvoud van de Unilever-groep en aan de flexibiliteit om op aandelen gebaseerde acquisities en afsplitsingen te doen. Bovendien leiden zij tot extra kosten, kunnen zij leiden tot koersverschillen tussen de gewone aandelen van de twee vennootschappen (waardoor arbitragemogelijkheden ontstaan) en komt het volle 'gewicht' van de groep niet tot uitdrukking in de nationale of regionale aandelenindices. ${ }^{8}$ Een groot aantal beursvennootschappen dat voorheen een duale structuur kende, schafte die

8. S. Hancock, M. Gray \& C. Sommelet, Dual-headed structures revisited, Global Counsel oktober 2002, p. 14-27. structuur in de afgelopen jaren af via een eenmakingsoperatie. Belangrijke voorbeelden hiervan zijn Royal Dutch Shell (voorheen: Koninklijke Nederlandsche Petroleum Maatschappij/ Shell Transport and Trading; in 2005), Ageas (het voormalige Fortis; in 2012) en RELX (het voormalige Reed Elsevier; in 2018). ${ }^{9}$ Het was dus niet geheel verrassend dat het bestuur van de Unilever-groep in het kader van kostenbesparingen en simplificering de beide juridische entiteiten wilde laten samensmelten, ook al liet Unilever na om aan te geven hoe hoog de baten (op termijn) zouden zijn.

\section{De keuze van het Unilever-bestuur voor een Nederlandse holding en de wijze om dit te bewerkstelligen}

Bijna een jaar na de aankondiging om de structuur van de Unilever-groep te vereenvoudigen, nam het Unilever-bestuur op 15 maart 2018 het besluit om de twee juridische Unileverentiteiten te laten opgaan in een nieuwe Nederlandse holding (hierna ook het 'nieuwe' Unilever genoemd). Deze holding zou drie divisies omvatten: Beauty \& Personal Care, Home Care en Foods \& Refreshments. De hoofdkantoren van Beauty \& Personal Care en Home Care zouden in Londen worden geplaatst en die van Foods \& Refreshment in Rotterdam. De keuze voor een Nederlandse holding werd, volgens het vrij summiere Unilever-persbericht van 15 maart 2018, puur ingegeven vanwege het feit dat de Unilever $\mathrm{NV}$-aandelen het grootste deel van de Unilever-groep vertegenwoordigen (55\%

9. Er zijn momenteel wereldwijd nog zes beursvennootschappen met een duale structuur: BHP Billiton, Carnival, Investec, Mondi, Rio Tinto en Unilever. Rond de eeuwwisseling waren dat er nog vijftien. 


\section{Maandblad \\ Ondernemingsrecht}

van de gewone aandelen) en dat deze NV-aandelen een grotere liquiditeit kennen dan de PLC-aandelen. ${ }^{10} \mathrm{Als}$ dit de daadwerkelijke redenen zijn geweest, dan is het enigszins verbazingwekkend dat het bestuur bijna een jaar nodig had om tot dit besluit te komen. In de op 11 september 2018 gepubliceerde aandeelhouderscirculaire staat dat het bestuur ook andere factoren in ogenschouw heeft genomen, 'waaronder in het bijzonder fiscale, regelgevings- en juridische aangelegenheden', maar niet duidelijk is welke dat precies zijn en hoe deze zijn gewogen.

In het persbericht van 15 maart 2018 werd tevens vermeld dat de unificatie zou worden gerealiseerd via een zogenoemde Scheme of Arrangement (hierna: Scheme) aan de PLC-zijde en via een Nederlandse juridische (driehoeks)fusie aan de NV-zijde. Een Scheme is een Brits herstructureringsmechanisme en is in essentie een door de Britse rechter goedgekeurd akkoord tussen de vennootschap enerzijds en de schuldeisers en aandeelhouders (of een klasse van deze aandeelhouders) anderzijds over een herstructurering, waaronder ook een overname. ${ }^{11}$ Een akkoord komt alleen voor rechterlijke goedkeuring in aanmerking als eerst een traject is doorlopen waarbij een aantal procedurevoorschriften in acht is genomen betreffende de aanbieding, de inhoud en de inrichting van het akkoord. Schuldeisers en aandeelhouders die door het akkoord worden geraakt, moeten in de gelegenheid zijn gesteld om zich via een stemming over het akkoord uit te spreken. De stemming geschiedt per klasse van schuldeisers en aandeelhouders in een fysieke vergadering. In de aandeelhoudersvergadering moet ten minste $50 \%+1$ van de aanwezige of vertegenwoordigde aandeelhouders met het akkoord instemmen en deze meerderheid moet ten minste driekwart van de ter vergadering uitgebrachte stemmen vertegenwoordigen. Als de rechter het akkoord vervolgens goedkeurt, is het verbindend voor alle aandeelhouders, dus ook voor diegenen die tegen het akkoord hebben gestemd. In de Scheme voor Unilever PLC werd voorgesteld dat de aandelen in Unilever PLC zouden worden omgeruild voor aandelen in het nieuwe Unilever, overeenkomstig een ruilverhouding van 1:1. Unilever PLC zou vervolgens een dochtermaatschappij van het nieuwe Unilever worden.

De juridische (driehoeks)fusie voorzag erin dat de speciaal voor de fusie opgerichte Unilever International Holding BV het gehele vermogen en alle rechtsverhoudingen van Unilever $\mathrm{NV}$ onder algemene titel zou verkrijgen en dat Unilever NV zou ophouden te bestaan. Het nieuwe Unilever zou, als enig aandeelhouder van Unilever International Holding BV, aandelen in haar kapitaal toekennen aan de aandeelhouders van Unilever NV overeenkomstig een ruilverhouding van 1:1. Het

10. Het gemiddelde dagelijkse handelsvolume in de Unilever NV-aandelen is 4,12 miljoen, tegenover 2,53 miljoen in de Unilever PLC-aandelen (bron: Bloomberg). De beurswaarde van Unilever NV bedroeg in september 2018 zo'n EUR 70 miljard, terwijl de beurswaarde van Unilever PLC ongeveer EUR 60 miljard bedroeg.

11. Deel 26 van de UK Companies Act 2006. besluit tot fusie diende door de algemene vergadering van Unilever NV te worden goedgekeurd met een gewone meerderheid van de ter vergadering uitgebrachte stemmen. Alleen als minder dan de helft van het geplaatste kapitaal op die vergadering aanwezig of vertegenwoordigd zou zijn, dan zou het besluit met ten minste twee derde van de uitgebrachte stemmen moeten worden genomen. ${ }^{12}$

Het persbericht van 15 maart 2018 noch de aandeelhouderscirculaire van 11 september 2018 bevat argumenten waarom voor de combinatie van de Scheme en de juridische (driehoeks)fusie was gekozen en niet voor alternatieven, zoals een openbaar bod van Unilever NV op de aandelen Unilever PLC of een grensoverschrijdende juridische fusie met Unilever NV als verkrijgende vennootschap en Unilever PLC als verdwijnende vennootschap. Een betere communicatie had zeker voor de Scheme wel voor de hand gelegen, mede omdat de drempels voor de aandeelhoudersgoedkeuring daarover zo hoog zijn. Zo wezen de Britse organisaties van particuliere beleggers, Sharesoc en de UK Shareholders Association, de Scheme af en riepen zij de om en nabij 36.000 Britse particuliere beleggers in Unilever PLC op om actief deel te nemen aan de stemming op de algemene vergadering. ${ }^{13}$ Mede door deze adviezen, gecombineerd met de Brexit-sentimenten, was de kans aanwezig dat niet zou worden voldaan aan de eis dat de meerderheid van de ter vergadering aanwezige of vertegenwoordigde aandeelhouders instemt met de Scheme. Daarnaast was het, door de weerstand van een aantal Britse institutionele beleggers, twijfelachtig of zou worden voldaan aan de eis dat de Scheme met ten minste $75 \%$ van de ter vergadering uitgebrachte stemmen wordt aanvaard. Paragraaf 5 gaat uitgebreid in op de bezwaren van de Britse institutionele beleggers, die werden onderschreven door de Britse organisaties van particuliere beleggers.

\section{Belangrijke voorwaarden voor unificatie en} plaatsing van het hoofdkantoor in Nederland

Hoewel dit niet uit het persbericht van 15 maart 2018 of de officiële transactiedocumentatie van 11 september 2018 blijkt, mag worden aangenomen dat er twee belangrijke voorwaarden waren voor het unificatieproces en het besluit om het nieuwe Unilever in Nederland te plaatsen. Dat waren een geslaagde inkoop van alle nog uitstaande financieringspreferente aandelen van Unilever NV en de afschaffing van de dividendbelasting in Nederland.

Een belangrijke doelstelling van de unificatie was het vereenvoudigen van de vennootschappelijke structuur. ${ }^{14}$ Een belangrijk obstakel om die doelstelling te verwezenlijken was het feit dat Unilever NV maar liefst vier soorten aandelen kende:

12. Art. 32 statuten Unilever NV jo. art. 2:317 lid 3 en 2:330 lid 1 BW.

13. Zie het op 21 september 2018 gepubliceerde statement van deze organisaties op www.sharesoc.org/sharesoc-news/uksa-and-sharesoc-votingre-unilever-resolutions/.

14. Zie p. 30 van het biedingsbericht d.d. 11 oktober 2017 inzake alle uitstaande preferente aandelen van Unilever (beschikbaar op www. unilever.com en op www.afm.nl). 
gewone aandelen, speciale aandelen, financieringspreferente aandelen $B$ en financieringspreferente aandelen C. De financieringspreferente aandelen werden door Unilever NV tussen 1927 en 1964 uitgegeven. In de loop der jaren verschaften de financieringspreferente aandelen de houders ervan onevenredig veel stemrecht in vergelijking met de kapitaalinbreng. Begin 2018 vertegenwoordigden de uitstaande financieringspreferente aandelen van Unilever NV om en nabij de $20 \%$ van het geplaatste kapitaal, terwijl de kapitaalinbreng minder dan $0,5 \%$ van het geplaatste kapitaal bedroeg. Teneinde de dominantie van de houders van financieringspreferente aandelen te mitigeren, is Unilever $\mathrm{NV}$ in het verleden overgegaan tot het certificeren van een groot deel van haar gewone aandelen en een gedeelte van de financieringspreferente aandelen. Het bij die gelegenheid opgerichte administratiekantoor had hierdoor in de praktijk een grote invloed op de besluitvorming in de algemene vergadering van Unilever NV. ${ }^{15}$ In de algemene vergaderingen van 2017 en 2018 vertegenwoordigde het administratiekantoor bijvoorbeeld ruim een derde van de uitgebrachte stemmen. De doelstelling van vereenvoudiging van de vennootschappelijke structuur van de Unilever-groep zou niet worden bewerkstelligd als na unificatie niet kon worden overgegaan op het principe van één aandeel, één stem. Na jaren van moeizame onderhandelingen tussen Unilever NV en de twee belangrijkste houders van de financieringspreferente aandelen - $97 \%$ van de financieringspreferente aandelen werd gehouden door de verzekeraars NN Group en ASR Nederland - werd op 9 augustus 2017 met deze partijen een akkoord bereikt over een openbaar bod van (een dochtermaatschappij van) Unilever PLC op alle financieringspreferente aandelen van Unilever NV. Dat bod had een waarde van in totaal ongeveer EUR 450 miljoen. ${ }^{16}$ Het bod was succesvol, zodat het op 26 oktober 2017 gestand werd gedaan. Inmiddels zijn alle financieringspreferente aandelen overgedragen aan Unilever NV. De speciale aandelen werden al door (een dochtermaatschappij van) Unilever NV gehouden. Unilever NV stelde voor om ten tijde van de effectuering van de unificatie alle financieringspreferente en speciale aandelen in te trekken en het administratiekantoor te ontbinden.

Een andere belangrijke voorwaarde voor het besluit om het hoofdkantoor van het nieuwe Unilever in Nederland te plaatsen, was de voorgenomen afschaffing van de Nederlandse divi-

15. Het administratiekantoor is in de algemene vergadering bevoegd te stemmen op de aandelen waarvoor door certificaathouders geen stemvolmacht is gevraagd, zie art. 2:118a BW.

16. De financieringspreferente aandelen gaven een in principe eeuwigdurend jaarlijks, relatief hoog, rendement van $6 \%$ respectievelijk $7 \%$. Al geruime tijd was duidelijk dat er een hoog prijskaartje hing aan het afkopen van deze vrij zekere toekomstige kasstromen. De overnamepremie bedroeg maar liefst tussen de $250 \%$ en $290 \%$ (zie het eerder aangehaalde biedingsbericht, p. 32). Het openbare bod leverde NN Group een boekwinst op van maar liefst EUR 250 miljoen en ASR Nederland van meer dan EUR 100 miljoen (bron: NN Group, derde kwartaalbericht 2017; ASR Nederland, jaarcijfers 2017). dendbelasting. ${ }^{17}$ Unilever PLC hoeft over haar dividenduitkeringen geen dividendbelasting in te houden, omdat het Verenigd Koninkrijk een dergelijke belasting niet kent. Unilever NV moet daarentegen over het aan haar aandeelhouders uitgekeerde dividend $15 \%$ dividendbelasting inhouden. Er is een groep aandeelhouders die deze dividendbelasting kan verrekenen met de in hun thuisland verschuldigde belasting, zoals Nederlandse belastingplichtigen. Zij kunnen de dividendbelasting verrekenen met de inkomstenbelasting en de vennootschapsbelasting. Andere belangrijke groepen van aandeelhouders van Nederlandse beursvennootschappen, zoals vermogensbeheerders en bepaalde beleggingsfondsen die zijn gezeteld in het Verenigd Koninkrijk, Frankrijk, Italië, Luxemburg, België, Spanje, Zweden en Noorwegen, kunnen de dividendbelasting niet of slechts gedeeltelijk verrekenen in hun thuisland. ${ }^{18}$ Deze vermogensbeheerders houden gezamenlijk om en nabij 30\% van alle Nederlandse beursgenoteerde aandelen. Aandeelhouders van Unilever PLC zouden mogelijk bezwaar maken tegen een bestuursbesluit om het hoofdkantoor in Nederland te plaatsen als dit gepaard zou gaan met fiscale nadelen. In het regeerakkoord van het in oktober 2017 tot stand gekomen kabinet-Rutte III was de afschaffing van de dividendbelasting inderdaad opgenomen. ${ }^{19}$ Echter, al vanaf de presentatie van het regeerakkoord kwam dit voornemen politiek en maatschappelijk onder vuur te liggen. In paragraaf 5.3 wordt hierop verder ingegaan.

\section{Bezwaren van aandeelhouders}

Al kort na bekendmaking van het Unilever-bestuursbesluit uitten met name aandeelhouders van Unilever PLC geregeld publiekelijk bezwaren tegen het Unilever-besluit. ${ }^{20}$ De meeste PLC-aandeelhouders onderschreven de strategische rationale van de eenmakingsoperatie, maar waren kritisch over de overwegingen van het Unilever-bestuur om zowel de statutaire zetel als het hoofdkantoor van het nieuwe Unilever in Nederland te plaatsen. De bezwaren spitsten zich in wezen toe op drie onderwerpen: (1) de niet-opname van de aandelen van het nieuwe Unilever in de FTSE UK-aandelenindices, zoals de FTSE 100 Index, de FTSE 350 Index en de FTSE All-Share

17. Dit blijkt niet uit de aandeelhouderscirculaire of de toelichting op de Scheme, maar uit het interview met de voormalige Chief Executive Officer (CEO) van Unilever, Paul Polman, in het Algemeen Dagblad van 24 november 2018 met de titel 'Dividenddebacle was voor Mark én mij een teleurstelling'. Hij stelde: 'Wij zijn altijd heel transparant geweest, al meer dan tien jaar. We hebben heel duidelijk tegen het kabinet gezegd: als je ooit wilt dat Unilever met zijn hoofdkantoor naar Nederland komt, kan dat nooit gebeuren met dividendbelasting.'

18. Brief d.d. 14 november 2017 van de staatssecretaris van Financiën inzake voorbeelden van niet-verrekenbare Nederlandse dividendbelasting (Kamerstukken II 2017/18, 34700, 54).

19. Regeerakkoord 2017-2021, Vertrouwen in de toekomst, 2017, p. 35.

20. Zo uitte Columbia Threadneedle, houder van $1,5 \%$ van de Unilever PLC-aandelen, al op 22 maart 2018 kritiek op het gebrek aan voorafgaande consultatie van aandeelhouders over het Unilever-bestuursbesluit en over de mogelijke niet-opname van de nieuwe Unilever-aandelen in de FTSE 100 Index. Zie The Times, Top investor Columbia Threadneedle angry at Unilever move, 23 maart 2018. Zie ook Financial Times, It's not too late to rethink Unilever going Dutch, 5 april 2018 en Financial Times, Unilever plc shareholders need to defeat unification plan, 22 juni 2018. 


\section{Maandblad}

Ondernemingsrecht

Index, (2) een mogelijke verslechtering van de corporategovernancestructuur en (3) onzekerheid over het afschaffen van de Nederlandse dividendbelasting. Deze factoren worden hierna besproken.

\subsection{De niet-opname van de nieuwe Unilever-aandelen in de FTSE UK-aandelenindices}

De Unilever PLC-aandelen zijn momenteel opgenomen in de FTSE UK-aandelenindices en de NV-aandelen in de Nederlandse, Euro- en Europa ${ }^{21}$-aandelenindices, zoals geconstrueerd door de indexaanbieders Euronext, MSCI, STOXX en FTSE Russell. In de op 11 september 2018 gepubliceerde toelichting op de Scheme schrijft Unilever dat het extremely unlikely is dat de aandelen van het nieuwe Unilever in de FTSE UK-aandelenindices zullen worden opgenomen, terwijl deze - in vergelijking met de huidige NV-aandelen - naar verwachting een groter gewicht zullen krijgen in de Nederlandse, Euro- en Europa-aandelenindices. De Unilever-groep had, volgens de toelichting op de Scheme, verschillende gesprekken met FTSE Russell over het behoud van de opname in de FTSE UK-aandelenindices, maar deze leidden niet tot een positief resultaat. $^{22}$

De regels voor opname van aandelen van een beursvennootschap die is gevestigd buiten het Verenigd Koninkrijk in de FTSE UK Indices zijn namelijk stringent. Voorwaarde is bijvoorbeeld dat een dergelijke vennootschap publiekelijk moet verklaren de principes van de Britse Corporate Governance Code zo goed mogelijk te zullen volgen. Ook moeten de principes van de Britse Pre-Emption Group inzake het behoud van het voorkeursrecht voor aandeelhouders bij aandelenemissies zo goed mogelijk worden toegepast, alsmede de Britse overnameregels uit de UK Takeover Code.$^{23}$ Blijkens het persbericht van 15 maart 2018 wilde Unilever voldoen aan de eerste twee eisen, maar was de laatste eis blijkbaar een brug te ver. De voormalige CEO van de Unilever-groep, Paul Polman, ${ }^{24}$ had in het verleden verschillende malen kritiek geuit op de Britse overnameregels. ${ }^{25} \mathrm{Hij}$ vond dat het bestuur van een beursvennootschap in een overnamesituatie ook de belangen van andere stakeholders dan uitsluitend die van aandeelhouders zou moeten dienen, en dat het daarvoor enige bescherming zou moeten krijgen. De Britse overnameregels verbieden juist dat het bestuur zelfstandig een bod frustreert en hebben als uitgangspunt dat aandeelhouders niet de mogelijkheid ontzegd mag worden om over de merites van een openbaar bod te beslissen. ${ }^{26}$

$\mathrm{Na}$ de publicatie van de toelichting op de Scheme grepen verschillende Britse institutionele beleggers de dreigende niet-

21. Exclusief het Verenigd Koninkrijk.

22. Toelichting op de Scheme, p. 40.

23. FTSE Russell, Ground Rules FTSE UK Index Series, regel 5.1.3.

24. Paul Polman is op 1 januari 2019 afgetreden als CEO van Unilever en is opgevolgd door de Brit Alan Jope.

25. Reuters, Unilever CEO urges UK to provide 'level playing field' after Kraft bid, 14 maart 2017.

26. Regel 21 uit de Britse Takeover Code. opname van de nieuwe Unilever-aandelen in de FTSE UKaandelenindices aan om publiekelijk hun zorgen te uiten over het bestuursbesluit. Met name de FTSE 100 Index is voor een aantal Britse institutionele beleggers een belangrijke aandelenindex. Soms volgt uit het contract dat deze beleggers met hun cliënten (Britse pensioenfondsen en/of Britse verzekeraars) hebben gesloten dat zij (een deel van) het voor deze cliënten beheerde vermogen beleggen conform de samenstelling en de gewichten van de aandelen die in de FTSE 100 Index zijn opgenomen. Daarnaast is deze index voor een aantal Britse institutionele beleggers een belangrijke graadmeter voor het benchmarken van hun beleggingsprestaties. Wanneer Unilever PLC op de dag van formele unificatie uit de FTSE 100 Index zou verdwijnen, dan zou dit tot een grondige herschikking van de index leiden. ${ }^{27}$ Het gevolg zou zijn dat institutionele beleggers de nieuwe Unilever-aandelen, die zij voor de Unilever PLC-aandelen zouden krijgen, terstond zouden moeten verkopen. De Britse institutionele beleggers Columbia Threadneedle Investments, Aviva Investors, Legal \& General Investment Management, City of London Investment Trust, Schroder Investment Management, Lindsell Train, M\&G Investment Management en Royal London Asset Management waren bevreesd dat dit de prijs van de Unilever-aandelen neerwaarts zou drukken en dientengevolge tot verliezen voor henzelf en voor hun cliënten zou leiden. Het was, althans volgens de publieke uitingen, voor hen een van de belangrijkste redenen om ruim vóór de datum van de algemene vergadering van Unilever PLC publiekelijk aan te kondigen tegen de Scheme te zullen stemmen. ${ }^{28}$ Of de niet-opname van de nieuwe Unilever-aandelen in de FTSE UK-aandelenindices daadwerkelijk een negatief effect op de prijs van de Unilever-aandelen zou hebben gehad, valt echter zeer te bezien. Aangezien het gewicht van de aandelen van het nieuwe Unilever in bepaalde regionale aandelenindices zou toenemen, ${ }^{29}$ en deze indices voor veel (wereldwijd beleggende) institutionele beleggers belangrijker zijn dan een nationale index, zouden andere insti-

27. De Unilever PLC-aandelen hadden op 28 september 2018 een gewicht van $2,4 \%$ in de FTSE 100 Index. De aandelen van slechts zeven andere beursvennootschappen kennen een hoger gewicht in deze index. Unilever zou in de index worden vervangen door een (veel) kleinere Britse beursvennootschap.

28. Zie bijv. het publieke statement van $M \& G$ Investment Management: www.mandg.com/ski/case-study-unilever/, en dat van Royal London Asset Management: www.royallondon.com/media/press-releases/2018/ october/rlam-against-forced-divestment-of-unilever-under-singlelisting/.

29. Zo zou het nieuwe Unilever naar verwachting het op twee na grootste gewicht in de Euro STOXX 50 Index krijgen. In september 2018 bezette Unilever NV de tiende plaats in deze index (bron: filing van Unilever NV d.d. 11 september 2018 bij de Amerikaanse beurstoezichthouder SEC; te vinden op www.sec.gov). In perspectief: ultimo april 2017 waren er wereldwijd 55 zogenoemde indextrackers met een belegd vermogen van in totaal zo'n EUR 13 miljard die de FTSE UKaandelenindices volgden, terwijl tegelijkertijd indextrackers met een belegd vermogen van in totaal zo'n EUR 40 miljard de Euro STOXX 50 Index volgden (bron: FTSE Russell en ETF Strategy). Het lag in de lijn der verwachting dat ook het gewicht van het nieuwe Unilever in de MSCI Europe en de MSCI EMU Index, twee andere veel getrackte Europese indices, zou toenemen in vergelijking met het gewicht van Unilever NV in deze indices. 
tutionele beleggers nieuwe Unilever-aandelen hebben moeten bijkopen. ${ }^{30}$

Wat hier ook van zij, het is opmerkelijk dat het Unileverbestuur de beleggerssentimenten over de niet-opname van de nieuwe Unilever-aandelen in de FTSE UK-aandelenindices zo heeft onderschat. ${ }^{31}$ Het Unilever-bestuur had in dat verband zijn voordeel kunnen doen met de ervaringen van Royal Dutch Shell bij haar unificatieproces in 2005. In een artikel waarin twee (voormalige) Shell-juristen terugblikken op dit unificatieproces valt bijvoorbeeld te lezen:

'De keuze voor een vennootschap naar Engels recht (en dus niet naar het recht van Nederland of een andere jurisdictie) leek al snel onontkoombaar. De nieuwe vennootschap diende namelijk met alle uitstaande aandelen in de FTSE 100 index op de beurs van Londen te worden opgenomen. Om hier zeker van te zijn was het noodzakelijk dat de rechtsvorm van de vennootschap die van een Engelse plc zou zijn. ${ }^{32}$

In de toelichting op de Scheme noch in de aandeelhouderscirculaire wordt uitgelegd op welke wijze het Unilever-bestuur de niet-opname in de FTSE UK-aandelenindices heeft gewogen tegenover de toename van het gewicht van het nieuwe Unilever in de Nederlandse, Euro- en Europa-aandelenindices, waarom Unilever niet voor de 'Shell-variant' heeft gekozen (de keuze voor de rechtsvorm van een Engelse plc met het hoofdkantoor in Nederland), en waarom het bestuur er niet voor heeft gekozen om de Unilever PLC-aandeelhouders een controlepremie toe te kennen, omdat deze groep aandeelhouders de 'controle' over 'hun' vennootschap zou opgeven.

\subsection{Verslechtering van de corporate- governancestructuur?}

In een beleggerspresentatie van 20 september 2018 is een sheet opgenomen (afgebeeld in figuur 2) waarin het Unileverbestuur een duidelijk overzicht verschaft van een 'verdere ver-

30. Waarbij ervan wordt uitgegaan dat de aanpassing van het Unilevergewicht in de nationale en regionale aandelenindices op hetzelfde moment gebeurt als de verwijdering van de Unilever PLC-aandelen uit de FTSE UK-aandelenindices.

31. In een toespraak tot de Unilever-werknemers op 11 september 2018 sprak toenmalig CEO Paul Polman vrij laconiek over de zorgen van de Britse institutionele beleggers: 'What we are saying to them is, if it's that important to you, change a little bit your remit, be a little bit more flexible, and you can certainly invest in our shares still which are traded in the UK' (transcript van de toespraak zoals op 11 september 2018 gedeponeerd bij de SEC; te vinden op www.sec.gov).

32. M.C.M. Brandjes \& J. Vegter, Een Koninklijke PLC Royal Dutch Shell, NJB 2006/298, p. 369-375. In dezelfde zin Ch.E. Honée, De Koninklijke is niet meer: lang leve Royal Dutch!(?), Ondernemingsrecht 2005/153. Vgl. ook de waarschuwing van de CEO van BHP Billiton in 2018 naar aanleiding van het voorstel van Elliott Capital Advisors om BHP Billiton PLC en BHP Billiton Limited te unificeren en om de statutaire zetel en het hoofdkantoor van het nieuwe BHP Billiton in Australië te plaatsen (Financial Times, BHP's investors may balk at unification if FTSE 100 membership jeopardised: CEO, 20 februari 2018). sterking van de corporate-governancestructuur' van de Unilever-groep na de unificatie.

Het Unilever-bestuur hoopte met deze verbeteringen de aandeelhouders van zowel Unilever NV als Unilever PLC tevreden te stemmen. Daarnaast mag niet onvermeld blijven dat het nieuwe Unilever zou doorgaan met de praktijk van het jaarlijks (her)benoemen van alle bestuurders, het vragen van een relatief beperkte machtiging aan de algemene vergadering om nieuwe aandelen uit te geven zonder voorkeursrecht voor bestaande aandeelhouders $(5 \%+5 \%)$ en het jaarlijks voor een adviserende stem voorleggen van het remuneratierapport aan de algemene vergadering. ${ }^{33}$ Vanuit $\mathrm{NV}$-aandeelhoudersperspectief zijn dit onmiskenbaar corporate-governanceverbeteringen, met name het voorstel om het administratiekantoor te ontbinden, de financieringspreferente aandelen in te trekken en de certificering van de aandelen op te heffen. Hierdoor zou voor het eerst sprake zijn van het voor aandeelhouders belangrijke principe van één aandeel, één stem. Ook het voorstel dat aandeelhouders die 'slechts' 3\% van het geplaatste kapitaal representeren een buitengewone algemene vergadering bijeen zouden kunnen roepen zonder rechterlijke machtiging, zou de positie van de aandeelhouders van Unilever NV versterken. ${ }^{34}$ Op een dergelijke vergadering kunnen de verzoekende aandeelhouders bijvoorbeeld voorstellen doen tot ontslag en benoeming van (nieuwe) bestuurders en tot wijziging van de statuten. ${ }^{35}$

Voor de Unilever PLC-aandeelhouders waren de voorgestelde corporate-governanceverbeteringen minder evident. Unilever PLC kende al het principe van één aandeel, één stem. Bovendien is het in het Verenigd Koninkrijk voor aandeelhouders vrij eenvoudig om voorstellen voor een bindende aandeelhoudersstemming geagendeerd te krijgen, waaronder ook voorstellen die liggen op het terrein van strategie en beleid. ${ }^{36}$ Veel Britse institutionele beleggers stonden met name argwanend tegenover het voorstel uit het regeerakkoord van het kabinetRutte III om besturen van Nederlandse beursvennootschappen een zogenoemde bedenktijd van 250 dagen te gunnen in het geval van aandeelhoudersvoorstellen om bestuurders te

33. Unilever PLC legde het remuneratierapport al jaarlijks ter adviserende stemming voor aan haar algemene vergadering, maar Unilever NV deed dit (nog) niet.

34. Hoewel dit recht niet bleek uit de toelichting op de Scheme (p. 50), maar wel uit het voorstel voor de statuten van het nieuwe Unilever (art. 8.2.1).

35. Bevestigd in het persbericht van Unilever van 1 oktober 2018, laatste gedachtestreepje.

36. Zie o.a. de ervaringen van het activistische aandeelhouderscollectief Follow This om drie jaar achtereen bindende voorstellen te agenderen om het duurzaamheidsbeleid van Royal Dutch Shell aan te scherpen. In Nederland is dit onmogelijk; zie HR 20 april 2018, NJ 2018/331 m.nt. Van Schilfgaarde (Fugro/Boskalis). 


\section{Maandblad}

Ondernemingsrecht

\section{And further strengthening our corporate governance}

\begin{tabular}{|c|c|c|}
\hline & Current practice for NV and PLC & New NV corporate governance \\
\hline Voting rights & Shareholders of PLC vote independently from NV & One constituency: One share, one vote principle \\
\hline Classes of shares & $\begin{array}{l}\text { - NV shares; NV preference shares with high-voting rights } \\
\text { - PLC shares }\end{array}$ & $\begin{array}{l}\text { - Single class of shares*, one global pool of liquidity } \\
\text { - No preference shares* }\end{array}$ \\
\hline $\begin{array}{l}\text { - Trust Office } \\
\text { - Depositary receipt } \\
\text { structure }\end{array}$ & $\begin{array}{l}\text { Trust Office exists in Unilever NV: Trust Office held } 77 \% \text { of } \\
\text { NV shares at } 31.12 .17 \text { and represented } 33 \% \text { of votes at } \\
2017 \text { NV AGM }\end{array}$ & $\begin{array}{l}\text { No trust office (as Trust Office and depositary receipt } \\
\text { structure will be terminated) }\end{array}$ \\
\hline $\begin{array}{l}\text { Convene a general } \\
\text { meeting }\end{array}$ & $\begin{array}{l}\text { - NV: District court at request of shareholders holding } \\
\geq 10 \% \text { of issued capital } \\
\text { - PLC: Shareholders holding } \geq 5 \% \text { of issued capital }\end{array}$ & $\begin{array}{l}\text { Shareholders with } \geq 3 \% \text { of issued capital can require a } \\
\text { general meeting to be convened within } 8 \text { weeks }\end{array}$ \\
\hline $\begin{array}{l}\text { - Nominate/propose } \\
\text { removal of director } \\
\text { - Table resolution }\end{array}$ & $\begin{array}{l}\text { - NV: Shareholders holding } \geq 1 \% \text { of issued capital } \\
\text { - PLC: Shareholders holding } \geq 5 \% \text { of issued capital; } \\
\text { or } 100 \text { shareholders each holding ca. } 3,200 \text { shares } *\end{array}$ & Shareholders holding $\geq 1 \%$ of issued capital \\
\hline $\begin{array}{l}\text { Amending Articles } \\
\text { of Association }\end{array}$ & $\begin{array}{l}\text { - NV: }>50 \% \text { of votes cast at general meeting } \cdots \text {, at } \\
\text { proposal of the Board } \\
\text { PLC: }>75 \% \text { of votes cast at general meeting, at proposal } \\
\text { of the Board or Shareholders }\end{array}$ & $\begin{array}{l}\geq 75 \% \text { of votes cast at general meeting, at proposal of the } \\
\text { Board or Shareholders }\end{array}$ \\
\hline $\begin{array}{l}\text { - Disapplication of } \\
\text { pre-emption rights } \\
\text { - Share buy-back } \\
\text { authority } \\
\text { - Capital reduction }\end{array}$ & $\begin{array}{l}\text { - NV: }>50 \% \text { of votes cast at general meeting } \\
\text { - PLC: }>75 \% \text { of votes cast at general meeting }\end{array}$ & $\geq 75 \%$ of votes cast at general meeting \\
\hline
\end{tabular}

Bron: beleggerspresentatie van 20 september 2018; beschikbaar op www.sec.gov.

ontslaan of te benoemen. ${ }^{37}$ Het inroepen van de bedenktijd schort onmiddellijk het recht van aandeelhouders op om bestuurders te benoemen, te schorsen en te ontslaan. ${ }^{38}$ De institutionele beleggers zien dit als een inbreuk op hun zeggenschapsrechten. Het kabinetsvoornemen noopte het Unileverbestuur om op 1 oktober 2018 een statement te publiceren dat het 'nu of in de toekomst' geen gebruik zal gaan maken van de wettelijke bedenktijd. ${ }^{39}$ Desalniettemin bleef de argwaan bestaan dat het Unilever-bestuur mede voor Nederland als jurisdictie had gekozen omwille van de betere mogelijkheden voor het bestuur om openbare biedingen af te wijzen en om aandeelhoudersvoorstellen niet ter bindende stemming op de agenda van een algemene vergadering te plaatsen. ${ }^{40}$ Dat deze punten niet in alle openheid waren benoemd en beschreven in de toelichting op de Scheme en in de aandeelhouderscirculaire, wakkerde het ongenoegen en de achterdocht onder veel Britse PLC-aandeelhouders alleen maar aan.

37. Zie o.m. de brieven van de Britse institutionele beleggers Aberdeen Standard Life, Baillie Gifford, Intrinsic Value Investors, Jupiter Asset Management en Schroder Investment Management voorafgaand aan de hoorzitting in de Tweede Kamer over de bescherming van Nederlandse beursvennootschappen d.d. 1 juni 2017 (te vinden op www. tweedekamer.nl).

38. Ontwerpart. 2:114b BW van het voorontwerp van het wetsvoorstel tot wijziging van Boek 2 van het Burgerlijk Wetboek in verband met het inroepen van een bedenktijd voor het bestuur van een naamloze vennootschap (te vinden op www.internetconsultatie.nl).

39. Persbericht van Unilever van 1 oktober 2018, derde gedachtestreepje.

40. Zo verklaarden o.m. Aviva Investors, Schroder Investment Management en City of London Investment Trust in de Britse pers en Intrinsic Value Investors in de Nederlandse pers.

\subsection{Onzekerheid over afschaffing Nederlandse dividendbelasting}

Zoals al in paragraaf 4 is gesignaleerd, barstte na de publicatie van het regeerakkoord van het kabinet-Rutte III een maatschappelijke en politieke discussie los over het voornemen om de Nederlandse dividendbelasting per 1 januari 2020 af te schaffen. De gehele oppositie uitte felle kritiek op het voorstel; het voorstel zou puur zijn ingegeven om het hoofdkantoor van Royal Dutch Shell in Nederland te behouden en om het hoofdkantoor van het nieuwe Unilever naar Nederland te krijgen. De coalitiepartijen waren knarsetandend met het voorstel akkoord gegaan. Het Unilever-bestuur heeft zelf aangevoerd dat de politieke onzekerheid over het afschaffen van de dividendbelasting een belangrijke factor is geweest bij de twijfel onder met name de Unilever PLC-aandeelhouders over het bestuursbesluit. ${ }^{41}$ Onduidelijk is of dit ook daadwerkelijk het geval is. Zo had het Unilever-bestuur zelf al een zogenoemd 'vervangend dividendbetalingsmechanisme' opgetuigd voor het geval de afschaffing van de dividendbelasting toch niet zou doorgaan. ${ }^{42}$ De uitkering van dividend via dit mechanisme zou fiscaal worden gezien als een terugbetaling van gestort

41. Dit blijkt o.m. uit het interview met Paul Polman in het Algemeen Dagblad van 24 november 2018. Hij zegt daarin: 'Op zich is het goed dat er discussie is. Maar als je een oppositiepartij hebt die zegt "wij gaan het meteen weer afschaffen als wij aan de macht komen" en je weet dat regeringen in twee seconden kunnen omslaan. Dat helpt niet mee, als je hier in Engeland maar een vrij krappe marge hebt om de verhuizing erdoor te krijgen.'

42. Aandeelhouderscirculaire, p. 19-20 en toelichting op de Scheme, p. 19 en 59-62. 
kapitaal waarover geen dividendbelasting hoeft te worden ingehouden. ${ }^{43}$ Het mechanisme zou beschikbaar zijn voor aandeelhouders van het nieuwe Unilever die de Nederlandse dividendbelasting niet zouden kunnen verrekenen met de in hun thuisland verschuldigde belasting. Het vervangend dividendbetalingsmechanisme zou op dezelfde manier worden vormgegeven als de vrij regelmatig bij Nederlandse beursvennootschappen voorkomende voorstellen tot (van dividendbelasting vrijgestelde) teruggave van kapitaal. ${ }^{44}$ De kapitaalteruggave zou worden gedaan ten laste van de vrij beschikbare agioreserve. ${ }^{45}$ Dit zou worden geëffectueerd door het geplaatste kapitaal van de vennootschap eerst te verhogen door het nominale bedrag per aandeel te verhogen. Vervolgens zou het geplaatste kapitaal weer met hetzelfde bedrag worden verlaagd. Om die kapitaalteruggave te realiseren moeten wel de statuten twee keer worden gewijzigd, wat goedkeuring behoeft van de algemene vergadering. Ook moet de algemene vergadering hebben ingestemd met de kapitaalteruggave ${ }^{46}$ en moeten crediteuren geen verzet tegen het besluit hebben aangetekend. ${ }^{47}$ Op deze manier verwachtte het Unilever-bestuur de komende jaren in ieder geval EUR 58 miljard van dividendbelasting vrijgestelde kapitaalteruggave te kunnen doen. Om dit bedrag in perspectief te plaatsen: de totale dividenduitkering van de Unilever-groep over boekjaar 2017 bedroeg EUR 3,9 miljard. ${ }^{48}$

Mede door de optuiging van dit mechanisme is het onduidelijk in hoeverre de politieke onzekerheid over de afschaffing van de Nederlandse dividendbelasting een rol heeft gespeeld in het verzet van Unilever PLC-aandeelhouders tegen het bestuursbesluit. Tegenover de opvatting van een portefeuillemanager van de Britse institutionele belegger Intrinsic Value Investors dat de Nederlandse dividendbelasting 'irrelevant' is

43. Art. 3 lid 1 onder d Wet DB 1965.

44. Zoals de kapitaalteruggave ter gelegenheid van de afsplitsing van de speciaalchemiedivisie van AkzoNobel en van de afbouw van de zakelijke kredietportefeuille van Van Lanschot Kempen in het najaar van 2018.

45. Agioreserve ontstaat als een vennootschap nieuwe aandelen uitgeeft en is het verschil tussen de emissieprijs en de nominale waarde van het aandeel.

46. Art. 2:99 lid 6 BW.

47. Art. 2:100 BW.

48. In het op 11 september 2018 gepubliceerde document 'Frequently Asked Questions - Simplification' (beschikbaar opwww.sec.gov) staat dat het Unilever-bestuur ook 'alternatieve structuren of maatregelen' zou overwegen om de impact van het eventuele behoud van de Nederlandse dividendbelasting te mitigeren. Mogelijk doelde het Unileverbestuur hier op het instellen van een mechanisme waardoor het voor bepaalde Britse institutionele beleggers te ontvangen dividend zou voortkomen uit een Engelse bron. Zodoende zou geen dividendbelasting hoeven te worden ingehouden; dit is het zogenoemde dividend access mechanism zoals wordt gebruikt door Royal Dutch Shell. Dat zou wel vereisen dat er twee klassen aandelen zouden moeten komen, hetgeen afbreuk zou doen aan de doelstelling van het Unilever-bestuur om de vennootschappelijke structuur verregaand te simplificeren, resulterend in één vennootschap, één hoofdkantoor en één aandelenklasse. Zie over het dividendtoegangsmechanisme van Shell J.L. van de Streek, Shell en de dividendbelasting, WFR 2018/118, p. 806-814. voor een beleggingsbeslissing, ${ }^{49}$ stond de opvatting van de medeoprichter van een andere Britse institutionele belegger, Lindsell Train, dat de mogelijke instandhouding van de Nederlandse dividendbelasting een 'nieuw risico' was en dat het vervangend dividendbetalingsmechanisme geen 'eeuwigdurende garantie' bood. ${ }^{50}$ Daarnaast wees de staatssecretaris van Financiën op het feit dat er vele duizenden kostbare en tijdrovende bezwaarprocedures lopen tegen de Nederlandse dividendbelasting, hetgeen zou onderstrepen dat voor veel beleggers de dividendbelasting wel degelijk een belangrijke kostenpost vormt. ${ }^{51}$

\section{Het bestuursbesluit wordt ingetrokken}

Op 5 oktober 2018, drie weken vóór de uitgeschreven buitengewone algemene vergaderingen, besloot het Unilever-bestuur de eenmakingsoperatie van Unilever NV en Unilever PLC te staken. In een op die dag uitgegeven persbericht schreef het bestuur dat het 'brede steun' had gekregen voor het streven naar een vereenvoudiging van de structuur van de Unilevergroep, maar erkende het tegelijkertijd dat het voorstel daartoe niet op de steun van 'een aanzienlijke groep aandeelhouders' kon rekenen. Het bestuur maakte verder duidelijk dat het nog steeds van mening is dat een vereenvoudiging van de duale structuur in het langetermijnbelang van de Unilever-groep is. Het bestuur kondigde aan de ontstane situatie met de Unilever-aandeelhouders te bespreken en verklaarde te zullen doorgaan met het versterken van haar corporate-governancestructuur. Daartoe zullen onder meer de nog uitstaande financieringspreferente aandelen worden ingetrokken. Tien dagen na het intrekken van het Unilever-bestuursbesluit besloot het kabinet-Rutte III om het voorstel tot schrappen van de Nederlandse dividendbelasting in te trekken.

\section{Afsluiting}

Ondanks de breed onderschreven strategische rationale mislukte de unificatie van Unilever NV en Unilever PLC. De combinatie van de volgende drie factoren deed het Unileverbestuur waarschijnlijk de das om.

Ten eerste de miskenning van de Nederlands-Engelse herkomst van Unilever. De Unilever-groep is in 1930 ontstaan uit een grensoverschrijdende fusie tussen een Nederlandse en een Britse vennootschap. Het bewerkstelligen van een zekere balans tussen de Nederlandse en Engelse inbreng in de Unilever-groep kenmerkt de geschiedenis van deze beursvennoot-

49. A. de Mol van Otterloo, Buitenlandse belegger niet enthousiast over afschaffing dividendbelasting, FD 24 augustus 2018. Zie ook T.A. Keijzer, Extra bescherming van Nederlandse beursondernemingen: noodzaak of hypocrisie?, MvO 2018, afl. 1-2, p. 1-9.

50. Reuters, Top 10 Unilever shareholder may vote against plan to go Dutch, 17 september 2018. Ook M\&G Investment Management en City of London Investment Trust verwezen in hun publieke verklaringen naar de mogelijke fiscale nadelen van de plaatsing van het hoofdkantoor van het nieuwe Unilever in Nederland.

51. Aanhangsel Handelingen II 2018/19, 13. 


\section{Maandblad}

schap. ${ }^{52}$ Vanuit deze geschiedenis, de huidige gevoeligheden rond de Brexit en het gegeven dat ten tijde van het bestuursbesluit zowel de CEO als de voorzitter van de Unilever-groep de Nederlandse nationaliteit had, is het enigszins merkwaardig dat bij de ultieme stap tot unificatie van de Unilever-groep de Nederlands-Engelse erfenis geen zichtbare plek kreeg in de voorgestelde nieuwe vennootschappelijke structuur. Het bestuur stelde voor om zowel de statutaire zetel als het hoofdkantoor van het nieuwe Unilever in Nederland te plaatsen.

Ten tweede het gebrek aan openheid over de factoren die hebben geleid tot het bestuursbesluit om zowel de statutaire zetel als het hoofdkantoor van het nieuwe Unilever in Nederland te plaatsen. Dat puur mathematische factoren (groter 'Nederlands' aandeel in de Unilever-groep en hogere liquiditeit in de Unilever NV-aandelen) de doorslag hebben gegeven, is weinig geloofwaardig. Het Unilever-bestuur heeft verzuimd helderheid te verschaffen over welke andere structuren zijn overwogen, waarom daar niet voor is gekozen, en welke belangrijke aspecten en doelstellingen daarbij een rol hebben gespeeld.

Ten derde het niet voorafgaand betrekken van de grootste aandeelhouders bij het nemen van het bestuursbesluit, onder het mom van 'vertrouwelijkheid'. ${ }^{53}$ Het bestuursbesluit kan inderdaad als koersgevoelig worden gekenschetst. Maar mede gelet op de benodigde goedkeuring door de algemene vergadering van zowel Unilever NV als Unilever PLC zou het voor de hand hebben gelegen om puur vragenderwijs van de grootste aandeelhouders te vernemen welke factoren zij zouden meewegen bij het beslissingsproces over de verschillende structuren. Wellicht dat in die fase al snel boven water was gekomen wat het belang is van de opname van de aandelen van de vennootschap in de diverse aandelenindices en hoe hun percepties zijn over de corporate-governancestelsels in Nederland en het Verenigd Koninkrijk. Deze factoren zouden dan wellicht een zwaardere rol hebben kunnen krijgen in het beslissingsproces over de uiteindelijke unificatiestructuur en over het juridische instrument om die structuur te realiseren.

52. Zie o.m. P. Frentrop, A. Izeboud \& R. Renes, 'Difficult and painful choices'; analyse van de lange termijn strategie van Unilever: totstandkoming, governance en uitvoering, Studie door Nyenrode Business Universiteit in opdracht van Eumedion, april 2011.

53. Aldus The Times, Top investor Columbia Threadneedle angry at Unilever move, 23 maart 2018. 